\title{
Research Article \\ KITCHEN GARDENING: A PROMISING APPROACH TOWARDS IMPROVING NUTRITIONAL SECURITY IN RURAL HOUSEHOLDS
}

\author{
SINGH V. ${ }^{*}$, YADAV K.S. AND TRIPATHI A.K.
}

ICAR-Krishi Vigyan Kendra, Sagar, 470002, Jawaharlal Nehru Krishi Vishwa Vidyalaya, Adhartal, Jabalpur, 482004, Madhya Pradesh, India

*Corresponding Author: Email - ksyadav20@rediffmail.com

\section{Received: May 14, 2018; Revised: May 25, 2018; Accepted: May 26, 2018; Published: May 30, 2018}

\begin{abstract}
Despite of sufficient food grain production at national level, malnutrition is still a public health concern in our country. India is also one of the leading nations in vegetable production but the problem of malnutrition especially the micronutrient deficiencies are very common among the rural households. The underlying cause may be the unawareness, illiteracy, inadequate availability of vegetables and fruits and low purchasing power of the households. As per Recommended Dietary Allowances, daily intake of vegetables should be $300 \mathrm{gm} /$ person including roots and tubers, green leafy and other vegetables. Keeping into consideration the high prevalence of malnutrition especially micronutrient deficiencies and inadequate availability of vegetables, Krishi Vigyan Kendra, Sagar has carried out 56 demonstrations using 1.40 ha area from the year 2007 to 2016 on nutritional kitchen gardening. Prior to this, a total of eight training programmes were conducted including 164 participants on importance and establishment of nutrition kitchen garden in the same villages. The major objective was to improve the availability of vegetables and nutrient intake at household level and to improve the knowledge of rural women regarding various technological aspects of kitchen gardening and its importance. For the conduction of demonstrations, families of 4-6 members were selected purposively. An area of $250 \mathrm{~m}^{2}$ was taken to establish kitchen garden for each family. A questionnaire was used to assess the pre and post training knowledge of participants regarding various aspects of kitchen gardening. The result of the study showed an improvement in availability of vegetables for consumption at both household and individual level. The average per capita availability of vegetables increased from 172 to $278 \mathrm{gm} / \mathrm{day}$. The knowledge level of beneficiaries has also been improved through training programmes.

Keywords- Kitchen garden, vegetables, per capita availability, RDA
\end{abstract}

Citation: Singh V., et al., (2018) Kitchen Gardening: A Promising Approach Towards Improving Nutritional Security in Rural Households. International Journal of Microbiology Research, ISSN: 0975-5276 \& E-ISSN: 0975-9174, Volume 10, Issue 5, pp.-1216-1219. DOl: http://dx.doi.org/10.9735/0975-5276.10.5.1216-1219

Copyright: Copyright@2018 Singh V., et al., This is an open-access article distributed under the terms of the Creative Commons Attribution License, which permits unrestricted use, distribution and reproduction in any medium, provided the original author and source are credited.

\section{Introduction}

Vegetables are major source of vitamins, minerals, and fibers; their nutritive and medicinal values in human life are well documented. The major vegetable crops of Sagar district are Tomato, Brinjal, Potato, Onion, Ginger, Chilli, Cauliflower and Beetroot. The average productivity of these crops is much lower (48.6 q/ha) than state $(52.4 \mathrm{~g} / \mathrm{ha})$ and national productivity $(171.1 \mathrm{q} / \mathrm{ha})$. Vegetables are very important part of a good diet as they contain various nutrients for many body functions. These vegetables also provide taste, palatability, better digestibility to us and increases the appetite. Vegetables are suitably grown in kitchen gardens as they are mostly short duration crops. A family can take vegetables from these kitchen gardens round the year. The nutritional home garden or kitchen garden is generally located close to the house and is used for growing vegetables, fruits, and other food crops for the family [1]. It not only saves our money and time but also can provide a healthy, useful and environment friendly hobby for whole family. Home gardens can help us in recycling of household waste especially when a compost pit is developed. One of the easiest ways of ensuring access to a healthy diet that contains adequate macro- and micronutrients is to produce many kinds of foods in the home garden. This is especially important in rural areas where people have low purchasing power and distant markets. Kitchen gardening directly provides food and nutritional security by making access to food that can be harvested instantly, prepared, and fed to family members, daily or whenever required. Home gardens are also becoming an increasingly important source of food and income for poor households in peri-urban and urban areas. Kitchen gardens can be grown in the spaces available at the backyard of the house or roof or it can be established with joint efforts on a common place or land.
There are many social benefits that have emerged from kitchen gardening practices, better health and nutrition, increased income, employment, food security within the household, and enhance in community social life. Apart from having a good amount of production of vegetables at national level, the per capita availability in diet is quite low in our country. The daily requirement of vegetable is around 300 gms as per ICMR but the availability is very low. Many of the rural families used to grow vegetables in their backyards for their household consumption. But still they lack in adequate consumption of vitamins and minerals because of unorganized cultivation of vegetables. Keeping in view the importance of vegetables in daily diets and its low availability, the Krishi Vigyan Kendra has conducted various trainings and demonstrations under Women in Agriculture discipline.

\section{Materials and Methods}

The present work was carried out by Krishi Vigyan Kendra in the villages namely Baddaua, Badona, Semadhana, Chitora, Baroda and Mainpani of Sagar district during the year 2007 to 2016. First, eight training programs were conducted in these villages with total female participants of 164 . The objective of the training was to upgrade the knowledge of rural women regarding the importance of the kitchen gardening and the technical aspects of its establishment. Pre and post knowledge data of trainees was collected with the help of an interview schedule. Data on their basic profile was collected which included the information regarding their caste, education, income, etc. During training programs, data on the major constraints for kitchen gardening was also collected. 
Table-1 Pre and post training knowledge of farm women regarding establishment of nutritional kitchen garden

\begin{tabular}{|c|c|c|c|c|c|}
\hline \multirow[t]{3}{*}{ SN } & \multirow[t]{3}{*}{ Particulars } & \multicolumn{4}{|c|}{ Knowledge of farm women $(\mathrm{N}=164)$} \\
\hline & & \multicolumn{2}{|c|}{ Before training } & \multicolumn{2}{|c|}{ After training } \\
\hline & & $\mathrm{n}$ & $\%$ & $\mathrm{n}$ & $\%$ \\
\hline 1 & Land preparation and layout & 122 & 74.39 & 158 & 96.34 \\
\hline 2 & Improved varieties & 24 & 14.63 & 112 & 68.29 \\
\hline 3 & Appropriate sowing time of various vegetables and their seed rates & 62 & 37.80 & 144 & 87.80 \\
\hline 4 & Nutrient management through organic and inorganic inputs & 36 & 21.95 & 126 & 76.82 \\
\hline 5 & Critical stages of irrigation & 52 & 31.70 & 142 & 86.58 \\
\hline 6 & Intercultural operations & 88 & 53.65 & 150 & 91.46 \\
\hline 7 & Use of organic plant protection measures & 27 & 16.46 & 153 & 93.29 \\
\hline 8 & Post harvest management and value addition & 74 & 45.12 & 160 & 97.56 \\
\hline
\end{tabular}

Table-2 Major constraints perceived in the establishment of nutrition kitchen garden

\begin{tabular}{|c|c|c|c|c|}
\hline \multirow[t]{2}{*}{ SN } & \multirow[t]{2}{*}{ Particulars } & \multicolumn{2}{|c|}{ Participants ( $\mathrm{N}=164)$} & \multirow[t]{2}{*}{ Rank } \\
\hline & & $\mathrm{n}$ & $\%$ & \\
\hline 1 & Unavailability of quality planting material and seeds of HYV vegetables & 124 & 75.60 & II \\
\hline 2 & Low availability of water for irrigation & 135 & 82.31 & I \\
\hline 3 & $\begin{array}{l}\text { Lack of technical knowledge related to establishment of nutritional kitchen garden } \\
\text { like improved varieties, seed rate, sowing time, major insect pest diseases and } \\
\text { their management, fertilizer and manure application, irrigation etc. }\end{array}$ & 112 & 68.29 & III \\
\hline 4 & Lack of interest in kitchen gardening & 74 & 45.12 & V \\
\hline 5 & Adoption of traditional practices for growing vegetable & 90 & 54.87 & IV \\
\hline 6 & Lesser priority is given to kitchen gardening than other farm activities & 71 & 43.29 & $\mathrm{VI}$ \\
\hline 7 & Lack of knowledge regarding preservation and processing of surplus produce & 56 & 34.14 & VII \\
\hline
\end{tabular}

Table-3 Per unit production and availability of vegetables before and after establishing nutrition kitchen garden

\begin{tabular}{|c|c|c|c|c|}
\hline Technology & $\begin{array}{l}\text { Average Yield } \\
\text { (kg/unit area) }\end{array}$ & $\begin{array}{c}\text { Average Per capita } \\
\text { availability } \\
\text { (gm/ day) }\end{array}$ & $\begin{array}{l}\% \text { change in } \\
\text { availability } \\
\text { (gm/day) }\end{array}$ & $\%$ RDA \\
\hline Farmers's Practice & 77.4 & 172.0 & - & 57.33 \\
\hline Recommended Practice & 125.1 & 278.0 & 61.6 & 92.66 \\
\hline
\end{tabular}

Table-4 Per capita availability of nutrients before and after establishing nutritional kitchen garden

\begin{tabular}{|l|c|c|c|c|c|}
\multicolumn{2}{r}{} & \multicolumn{2}{c}{$\begin{array}{c}\text { Per capita availability of } \\
\text { nutrients/day }\end{array}$} & \multicolumn{4}{c|}{$\begin{array}{c}\text { Difference } \\
(\%)\end{array}$} \\
\cline { 2 - 6 } & Before & After & Before & After & +3.93 \\
\hline Protein(g) & 3.42 & 5.78 & 5.70 & 9.63 & +30.35 \\
\hline Iron (mg) & 1.78 & 6.94 & 10.47 & 40.82 & +32.61 \\
\hline Calcium (mg) & 120.6 & 316.3 & 20.1 & 52.71 & +36.32 \\
\hline Beta-carotene(mcg) & 2302.7 & 4046.2 & 47.97 & 84.29 & +144.0 \\
\hline Vitamin C(mg) & 92.6 & 150.2 & 231.5 & 375.5 & +15.49 \\
\hline Folic acid(mcg) & 15.7 & 46.62 & 7.85 & 23.31 & \\
\hline
\end{tabular}

To find out the constraints in vegetable production, Participatory Rural Appraisal (PRA) technique was used. Preferential ranking technique was utilized to identify the constraints faced by the rural women in kitchen gardening. After that, 56 households were selected through purposive sampling technique by screening households based on their willingness and interest to establish kitchen garden in their farm or in their backyard to ensure nutrition security. It has also been ensured that the family should be of 4-6 members. For individual household, an area of $250 \mathrm{~m} 2$ was taken for the establishment of nutrition kitchen garden. The study was conducted in both the kharif and rabi seasons. Krishi Vigyan Kendra has provided seed and planting material of improved varieties to the selected households. For kharif season, the vegetables selected for kitchen garden included amaranthus, okra, bottle gourd, sponge gourd, bitter gourd, brinjal, tomato, cow pea, spinach, and radish whereas in rabi season, they were provided seeds/planting material of coriander, fenugreek, spinach, radish, carrot, beet root, cauliflower, cabbage, tomato, brinjal, chilli and green pea. To assess the impact of establishing nutrition kitchen garden in the rural households, average yield per unit was obtained. A dietary survey was done in the selected households in order to assess their food consumption pattern before and after establishment of kitchen garden using 24 hour dietary recall method. The nutrient availability to every individual member of the household was calculated using the food composition tables given by Gopalan, et al., [2]. Then the nutrient availability was compared with the recommended dietary allowances given by ICMR (2010) for Indians. The data obtained was finally statistically analyzed for its significance.

\section{Results and Discussion \\ Training}

\section{General profile of the respondents}

A total of 164 rural women were participated in the training program. They were of 19 to 56 years of age group. The mean age was $29.76 \pm 7.97$ years. Most of the females were educated upto primary level (35.36\%) and among them $19.51 \%$ were found illiterate. Majority of participants ( $52.43 \%$ ) belonged to other backward class followed by general caste $(28.04 \%)$ and schedule caste. Their per capita income ranged between Rs. 400 to 2300 per month with a mean of Rs. $1031.48 \pm$ 486.81. Training helps in improving knowledge and skill and changes the attitude of the people. The knowledge of the participant women was assessed through collection of data through an interview schedule before and after training programs. Data obtained is presented in [Table-1] and [Fig-1] showed an increase in the knowledge of participants after their participation in training on various aspects of kitchen gardening. Least (14.63\%) rural women had knowledge on improved varieties whereas highest knowledge was observed on land preparation aspect $(74.39 \%)$ before the training. After training, their knowledge has been increased in all the aspects of vegetable production through kitchen gardening. A total of $97.56 \%$ rural women showed knowledge on post harvest and value addition followed by land preparation and layout (96.34\%), and so on. Malabasari and Hiremath, also reported an increase in the knowledge of rural women after providing them training on various aspects of agricultural and home sciences [3]. 


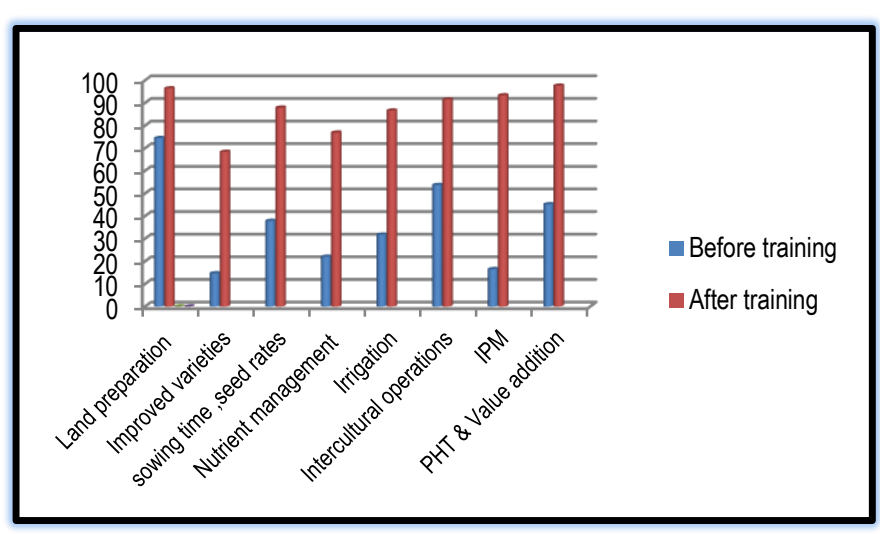

Fig-1 Percent of rural women having knowledge on various kitchen gardening aspects before and after training

According to them, training program helped incapacity building of rural women by creating awareness, increasing the knowledge about innovative technologies, and practicing improved skills which helps in the empowerment of rural women. During conduction of training on nutritional kitchen gardening, some constraints faced by rural women have also been perceived. Data presented in [Table-3] showed that availability of water for irrigation is the major constraint for production of vegetables in these areas. Unavailability of quality seed material and lack of technical knowledge ranked second and third constraint in this regard. Other constraints found included lack of interest in cultivation, traditional practices of vegetable production, not giving much priority to kitchen gardening etc. Several other studies were also conducted to find out these constraints in establishing a kitchen garden in rural areas. In a similar study conducted at Burdwan district of West Bengal, it was found that input constraint was most important constraint as it was ranked in 1 st position [4]. This was followed by technical constraints, sociocultural constraints and post-harvest constraints which were accorded II, III and IV ranks in rank order by the respondents. Another study reported the unavailability of quality planting material and seeds of HYVs of vegetable, less availability of water for irrigation, lack of knowledge about improved varieties, seed rate and sowing time, lack of knowledge about seed treatment, high soil pH and EC, lack of knowledge regarding major pests and diseases identification and their management and lack of interest among rural youth were reported major bottlenecks in successful adoption of kitchen gardening [5]. Similar results are also reported by Biswas and Jamir [6].

\section{Front Line Demonstration}

Under frontline demonstration of Krishi Vigyan Kendra, Sagar, a total of 56 demonstrations on kitchen garden has been conducted in the adopted villages. Each garden was established in $250 \mathrm{~m}^{2}$ area. The result presented in [Table-3] showed that the average yield of the vegetables increased from $77.4 \mathrm{~kg} / \mathrm{unit}$ in farmers practice to $125.1 \mathrm{~kg} / \mathrm{unit}$ under demonstration. With the result, the average per capita consumption of vegetables increased $61.6 \%$. Before plantation of kitchen garden, average per capita availability and consumption of vegetables was $57.33 \%$ of Recommended Dietary Allowances which was increased up to 92.66 $\%$. It has also been observed that the consumption of roots and tubers was more common in comparison to green leafy vegetables. After demonstration, consumption of vegetables increased especially of green leafy vegetables. Awasthi, et al., also reported increased per capita vegetable consumption after plantation of kitchen garden in Kanpur dehat and Kushinagar districts of Uttar Pradesh [7]. In another study carried out in Rudrapur block of US Nagar district, where good quality hybrid and improved varieties of vegetable seeds were supplied to the farm women to grow in an area of 0.07 ha. area. They found that the vegetables harvested were utilized for home consumption and the excess seedlings of cauliflower, cabbage, radish, and carrot were distributed to neighboring farm families. These vegetables were also dried and stored in powdered form as well as in dried pieces for later consumption [8]. Availability of vegetables in terms of nutrient before and after establishment of kitchen garden is presented in [Table-4]. Per capita availability of nutrients/day increased significantly after kitchen gardening intervention. It is obvious from [Table-4] that $3.93 \%$ protein, $30.35 \%$ iron, $32.61 \%$ calcium, $36.32 \%$ beta-carotene, $144 \%$ vitamin C and $15.49 \%$ folic acid of RDA were more available to individual after demonstration when compared with farmers practice. In Ranga Redddy district of Andhra Pradesh, establishment of nutrition garden as a community level strategic intervention program in 60 households revealed that the percent intake of Calcium, Iron and Vitamin $A$ at the end of the intervention showed an increase of $15 \% 11 \%$ and $55 \%$ respectively [9]. Findings of Chayal, et al., [10] and Yusuf, et al., [11] also supported the study.

\section{Conclusion}

Despite having good amount of vegetable production at national level, the per capita availability of vegetables is still less from the recommended dietary allowances.

Kitchen garden can be established at household or community level in order to ensure the daily supply of fresh vegetables in the diets.

Low availability of water for irrigation was perceived as major constraint in establishing a kitchen garden.

Average per capita availability of vegetables increased from $172 \mathrm{gm} /$ day to 278 $\mathrm{gm} /$ day after kitchen gardening was done in selected families.

Application of research: Trainings and front-line demonstrations were provided to farm women to increase their knowledge about gardening and to ensure the adequate supply of vegetables to selected farm families.

Research Category: Kitchen gardening, nutritional security

\section{Abbreviations:}

OFT: On farm trials

FLD: Front line demonstration

Acknowledgement / Funding: Author thankful to ICAR-Krishi Vigyan Kendra, Bhopal Road, Sagar, 470002, Jawaharlal Nehru Krishi Vishwa Vidyalaya, Adhartal, Jabalpur, 482004, Madhya Pradesh, India

\section{*Principle Investigator: Dr Vinita Singh}

University: Jawaharlal Nehru Krishi Vishwa Vidyalaya, Adhartal, Jabalpur, 482004, Madhya Pradesh

Research project name or number: OFT \{On farm trials\} and FLD \{Front line demonstration\}

\section{Author Contributions: All author equally contributed}

Author statement: All authors read, reviewed, agree and approved the final manuscript

\section{Conflict of Interest: None declared}

Ethical approval: This article does not contain any studies with human participants or animals performed by any of the authors.

\section{References}

[1] Jana H. (2015) Rashtriya Krishi, 10(2),13-16.

[2] Gopalan C.,Rama Shastri B.V. And Balasubramanian S.C. (1989) Nutritive value of Indian foods. Revised and updated by Narasingha Rao B.S., Deosthala Y.G. and Pant K.C. NIN, Hyderabad

[3] Malabasari R.T. and Hiremath U.S. (2016) J Farm Sci., 29(2), $251-$ 256.

[4] Sethy S., Sarkar S. and Kumar M. (2010) Ind. Res. J. Ext. Edu., 10 (2),89-92.

[5] Sharma K., Singh G., Dhaliwal N.S. and Yadav V.P.S. (2011) J. Comm Mobilization and Sus. Dev., 6(1), 096-099.

[6] Biswas P.K. and Jamir S. (2015) Int. J. Farm Sci. 5(3), 207-211. 
[7] Awasthi N., Sahu A., Chandrakala and Singh K. (2016) Advances in Social Res., 2(1), 49-51.

[8] Singh P., Pandey A., Tiwari C. and Sharma D. (2016) J. Rural Dev., 35(4), 80-83

[9] Vani Bhushanam G. and Usha Rani M. (2013) Am. Int. J. Res. in Formal, Applied \& Natural Sci., 3(1), 78-81.

[10] Chayal K., Dhaka B.L., Poonia M.K. and Bairwa R.K. (2013) Asian J Home Sci., 8(2),607-609.

[11] Yusuf A.M., Mustaque A.M. and Badirul I.M. (2008) In:Proceeding of National workshop on multiple cropping held at Bangladesh Agricultural Research Council, Farmgate, Dhaka, Bangladesh on 2324 April, 2008. 